\title{
David Gover: Top 3 differentials in vascular and interventional radiology: a case review
}

\section{Thieme, New York Stuttgart Delhi Rio de Janeiro, 2019306 p., format 28 X 21.5 X $1.5 \mathrm{~cm}, 425$ illustrations ISBN 978-1-62623-356-0 eISBN 978-1-62623-357-7}

\section{Bruno Grignon ${ }^{1}$}

Received: 23 July 2019 / Accepted: 26 July 2019 / Published online: 30 July 2019

(c) Springer-Verlag France SAS, part of Springer Nature 2019

This work aims at providing complete exam preparation and learning tool in the field of vascular and interventional radiology, using the format of the series "Top 3 differentials in radiology_a case review".

An amount of 144 cases is presented according to this format, organized as a two-page unit. The left page provides clinical information and one to four images, as the right page proposes key finding, top 3 differentials diagnoses or management considerations, additional important considerations, final diagnosis, clinical pearls, and resources for additional learning.

The book is divided into five parts, successively entitled: (1) preprocedural cases. (2) Procedural cases, (3) Aunt Minnies ...because, sometimes, "it is what it is", (4) interventional radiology anatomy, and (5) postprocedural cases. An index of differential diagnosis, as well as an index of key findings, is presented at the end of the book. In addition to the book, a complimentary online version is also available.

The author is David Gover, MD, Chief, Vascular and Interventional Radiology, David Grant USAF Medical Center, Travis Air Force Base, and Associate Clinical Professor, Volunteer Faculty Series University of California, Davis California. Four American contributors have collaborated in writing this book.
This attractive book encompasses the main current topics of vascular and interventional radiology of the daily practice. Well-illustrated, pleasantly presented, it aims at being a very practical and pedagogical tool, providing various tables and detailed algorithms and dealing with important management considerations, as well as with major teaching points. The only remark is that there is no real logic order in the successive cases that could have added its pedagogical value.

Chiefly devoted to radiology and interventional radiology residents, this concise and high-yield work may also be a useful tool for other physicians.

Author contributions BG: manuscript writing and editing.

\section{Compliance with ethical standards}

Conflict of interest The author declares that he has no conflict of interest.

Publisher's Note Springer Nature remains neutral with regard to jurisdictional claims in published maps and institutional affiliations.
Bruno Grignon

b.grignon@chu-nancy.fr

1 University of Lorraine, CHU Nancy, Nancy, France 